\title{
Agency Relationship in Budgeting at Inclusion Schools in Gunungkidul District
}

\author{
Risma Wira Bharata ${ }^{1 *}$, Eko Suwardi ${ }^{2}$, Mimin Nur Aisyah $^{3}$ \\ ${ }^{1}$ Tidar University, Indonesia, rismawirab@untidar.ac.id *orresponding authors \\ ${ }^{2}$ Gadjah Mada University, Indonesia, e.suwardi@ugm.ac.id \\ ${ }^{3}$ Universitas Negeri Yogyakarta, Indonesia,mimin_nuraisyah@uny.ac.id *corresponding authors
}

\begin{abstract}
This study explores the effect of budgetary participation on budgetary slack with organizational culture as an intervening variable in inclusive schools. This study used a survey method by distributing questionnaires consisting of six questions for budgetary slack, five questions budget participation, and 23 questions organizational culture. Used purposive sampling, the study included 100 inclusive school principals and ten education office staff who handled the inclusive school budget. Data were analyzed through a path analysis by using PLS. This study shows that budgetary participation affects organizational culture but has no effect on budgetary slack. Moreover, organizational culture does not mediate the relationship between budget participation and budgetary slack. The Office of Education and Inclusive Schools are suggested to establish better communication and strengthen an organizational culture that can encourage inclusive schools to participate in budgeting to reduce budgetary slack in inclusive education.
\end{abstract}

Keywords: Budget Participation, Budgetary Slack, Organizational Culture

\section{Hubungan Keagenan dalam Penganggaran pada Sekolah Inklusi di Kabupaten Gunungkidul}

\begin{abstract}
Abstrak
Penelitian ini bertujuan untuk menyelidiki pengaruh partisipasi anggaran terhadap senjangan anggaran dengan budaya organisasi sebagai variabel intervening pada sekolah inklusif. Penelitian ini menggunakan metode survei dengan menyebarkan kuesioner yang terdiri dari 6 pertanyaan untuk senjangan anggaran, 5 pertanyaan partisipasi anggaran, dan 23 pertanyaan budaya organisasi. Sampel menggunakan purposive sampling, yang meliputi 100 kepala sekolah inklusif dan 10 pegawai dinas pendidikan yang menangani anggaran sekolah inklusif. Analisis data menggunakan analisis jalur dengan PLS. Penelitian ini menemukan bahwa partisipasi anggaran berpengaruh terhadap budaya organisasi namun tidak dapat menemukan pengaruh partisipasi anggaran terhadap senjangan anggaran. Penelitian ini tidak membuktikan bahwa budaya organisasi dapat memediasi hubungan antara partisipasi anggaran dan senjangan anggaran. Dinas pendidikan dan sekolah inklusif diharapkan dapat menjalin komunikasi yang lebih baik dan memperkuat budaya organisasi yang dapat mendorong sekolah inklusif untuk berpartisipasi dalam penyusunan anggaran sehingga mengurangi senjangan anggaran dalam pendidikan inklusif.
\end{abstract}

Kata kunci: Partisipasi Anggaran, Senjangan Anggaran, Budaya Organisasi

\section{INTRODUCTION}

The education system for persons with disabilities in Indonesia is regulated through the Law of the Republic of Indonesia No. 20 of 2003, which consists of inclusive education and special education. However, the implementation of inclusive education in Indonesia still faces various problems. The concept of inclusive education has not been accommodated in laws, government regulations, and ministerial regulations. This concept is seen as a lack of infrastructure, a lack of teachers, a rigid curriculum, and a lack of community support for inclusive education (Handayani, T., \& Rahadian, 2013). This is supported by (Andiyani \& 
Ro'fah, 2014) that in implementing inclusive education, inclusive education's philosophical and normative foundations are not sufficient to become operational and applicable bases for teachers. Fikri (2014) also added that in the process of making inclusive policies, the involvement of people with disabilities is essential to influence the government. However, in existing policies or regulations, people with disabilities committed to implementing inclusive education are still minimal (Fikri, 2014). Hanjarwati and Aminah (2014) revealed that the implementation of inclusive education still faces obstacles in implementing the Mayor's Regulation, such as a lack of awareness of inclusive schools, a lack of understanding of teachers about how to serve and assist with special needs, and not all school facilities are accessible. In terms of the curriculum, Mayasari (2016) expressed that the implementation of the inclusive school curriculum has a lot of inhibiting factors, such as inefficient learning time, lack of teachers' understanding on handling children with special needs, and the unavailability of special personnel for taking deaf children and mentally disabled children, or the absence of a special companion teacher. The issue of inclusive education is still problematic in its implementation, even though regulations clearly regulate it.

With these various inclusive education problems, it is necessary to increase the understanding of inclusive education for parents, teachers, and community leaders. These efforts are needed to increase the support and participation in the implementation of inclusive education. Coordination between the inclusive school and the Education Office must also be improved to gain accessibility and services for children with special needs. One of the issues that deserve attention is the limited funding for the implementation of inclusive education. Inclusive schools do not annually accept inclusive funds from the government. Even if inclusive funds are available, then allocating funds is more focused on inclusive socialization activities than inclusive operational education (Witasoka, 2016). Besides, Wati (2014) concluded that inadequate education funding, facilities, and infrastructure and the lack of special assistant teachers were among the main obstacles to the inclusive education program. The priority scale must be applied in budget allocation so that government assistance funds are used for inclusive schools that need these funds. The aid is expected not to cause new problems for inclusive schools. Therefore, the budgeting process for implementing inclusive education can be carried out by involving budget participation from inclusive schools. Thus, the lack of cooperation from various parties such as the community, professional experts, and the government can be overcome so that inclusive education can run well (Tarnoto, 2016).

This study aims to see the relationship between the Education Office as a principal and inclusive schools as agents discussed in agency theory. Agency theory describes the budget preparation process seen from the formal relationship between principals and agents (Raharjo, 2007). Agency problems can arise because of differences in interests between principals and agents (Jensen \& Meckling, 1976). In this case, the principal, namely the Education Office, is interested in ensuring that the government's inclusive education program can run. Then, inclusive schools as agents are interested in educating children with disabilities properly according to their needs. 
One of the problems in budget participation is budgetary slack, which is the difference between budget targets and budget realization (Anthony, R. N., \& Govindarajan, 2000). Budget slack will prevent budget proposers from performing their best because they tend to loosen up the targets they set. Based on the results of the initial study conducted by the author through interviews with the principal of inclusive schools, it is identified that the education office provides inclusive programs that are not following the proposal of inclusive schools. For example, the education office directly provides a budget for ram and glading blocks, even though schools inclusive yet need it. On the other hand, sometimes inclusive schools reduce inclusive education funding to achieve its realization easily. Young (1985) said that budget participation would create budgetary slack, while Onci (1973) stated that budget participation would minimize the budgetary slack occurrence. Research (Kartika, 2010) and (Djasuli, M., \& Fadilah, 2011) stated that budget participation affects budgetary slack. However, study (Alfebriano, 2013) found that budget participation does not affect budgetary slack.

This study includes organizational culture as an intervening variable that connects budgetary participation and budgetary slack. Inclusive education mandated by law since 2003 will form an inclusive organizational culture to educate children with disabilities well and sincerely (President of the Republic of Indonesia, 2003). Supentanginingrum (2016) stated that for inclusive school members to realize good inclusive education, creating an inclusive organizational culture must always be fostered (Suprehiningrum, 2016). With an inclusive organizational culture that has been formed, budget participation from inclusive schools will be conveyed to the education office so that no budgetary slack will occur because the budget is adjusted to the inclusive school's needs. This argument is supported by Indriani \& Yusuf (2014) that found that budget participation affects budgetary slack, which in turn, organizational culture acts as a moderating variable for the relationship between budgetary participation and budgetary slack (Indriani, L., \& Yusuf, 2014). On the other hand, Huda et al. (2014) stated that organizational culture does not moderate the effect of budget participation on budgetary slack (Huda, K., Sinarwati, N. K., Herawati, N. T., \& AK, 2014). Besides, Prawira \& Wirasedana (2016) examined organizational culture as a mediating variable for the relationship between budgetary participation and budgetary slack (Prawira, H., \& Wirasedana, 2016). Several studies such as (Indriani, L., \& Yusuf, 2014) and (Huda, K., Sinarwati, NK, Herawati, NT, \& AK, 2014) regarding organizational culture place it as a moderating variable, but only a few studies such as (Prawira, H., \& Wirasedana, 2016) that used organizational culture as an intervening variable. Therefore, this study uses organizational culture as an intervening variable to determine organizational culture's role influenced by budget participation and influencing budgetary slack.

Based on variations in previous studies' results, the authors would like to re-examine the effect of budget participation on budgetary slack with organizational culture as an intervening variable in the context of the relationship between the education office and inclusive schools in the implementation of inclusive education in Gunungkidul. Gunungkidul Regency itself is the first district to implement inclusive education in the Yogyakarta Special Region Province. 


\section{Literature Review and Hypothesis Development}

In terms of agency theory, the implementation of inclusive education involves two parties, namely the Education Office as the principal and the Inclusive School as the agent. Agency theory tries to explain the budgeting process in the formal relationship between principals and agents (Raharjo, 2007). The two interested parties will often have conflicts of interest. This agency problem occurs because agents have different principal goals (Jensen \& Meckling, 1976). The principal party (the Education Office) is interested in making the inclusive school program from the government-run.

In contrast, the agent (Inclusive School) is interested in educating children with disabilities correctly and adequately according to their needs. Agents can communicate with principals as expected by maximizing their interests in budgeting (Raharjo, 2007). However, agency theory assumes that agents are motivated by interests, agents are rational actors, and are risk-averse (Stroh, L. K., Brett, J. M., Baumann, J. P., \& Reilly, 1996).

These conflicts of interest may occur in the process of program proposal and budget preparation. The method of proposing programs and budgeting in government is a political process. There is a tug of war of individual or group interests for their welfare. If only the government determines the program and prepares the budget, it can cause budgetary slack, namely the difference between planned performance targets and actual performance capabilities (Douglas, PC, \& Wier, 2000). Coalition members use the gap to satisfy personal motives that may not be stated explicitly approved (Onci, 1973). Inclusion schools will compile a budget that increases costs and lowers income, compared to the proposed best estimate, so that targets will be easily achieved (Budi, 2013). Agency theory proposes that organizations' primary goals are to minimize costs and maximize efficiency (Stroh, L. K., Brett, J. M., Baumann, J. P., \& Reilly, 1996). Principal and agent analysis in behavioral accounting research problems regarding managers' participation in the budgeting process (Magee, 1980). Agency theory observes symptoms of budgetary slack described as inefficiency or loss of income from symmetrical information on decisions (Raharjo, 2007). The majority of participants slacked their budget because they only obeyed orders from their direct superiors, even though they were considered unethical (Grediani, 2010). This incident occurred because the education office and the inclusive school did not communicate in programming and budgeting, so that there was no budget participation.

Participation is a concept used to describe the extent to which subordinates are allowed to choose their programs in action (Milani, 1975). Participatory budgeting will enable associates to carry information gaps to set performance standards, leading to higher job performance and higher job satisfaction (Young, 1985). In the process of budgeting participation, the principal (Education Office) will receive information on program proposals from the agency (inclusive school) to create an effective and efficient budget. The budget for the proposed inclusive education program must involve the education office and inclusive schools. Inclusive schools must be engaged in program proposal and budget preparation. At the same time, the education office listens to the suggestions that have been submitted by inclusive schools so that the communication process is well established. 
Participation in budgeting is very beneficial for centralizing dynamic implementation (Anthony, R. N., \& Govindarajan, 2000). This participation process aims to provide the best solution between the principal (education office) and the agent (inclusive school). The education office that runs the inclusion program and its budget has more information about government budgeting conditions. On the other hand, inclusive schools also have better information about children with disabilities in the teaching and learning process. Lack of communication between the two parties can cause budgetary slack between inclusive schools and the education office. Anticipating measures for budgetary slack between the education office and inclusive schools in participatory budgeting are expected to be bridged by the culture of inclusive organizations that have been formed in the education office and inclusive schools. Organizational culture resulting from the collective agreement will make members of the organization sense responsibility in implementing essential aspects of the organizational culture (Agusti, 2012). This, reinforced by Suprehiningrum (2016), stated that creating an inclusive culture must always be fostered so that school members can realize the practice of inclusive education and learning that they should be (Suprehiningrum, 2016). Based on previous research, this study suspects that organizational culture in inclusive schools will be a moderating variable between budget participation and budgetary slack.

In carrying out the inclusive education program, a budget is needed to finance all teaching and learning processes. The budget is prepared based on the teaching and learning program in inclusive schools proposed by the school as the implementer of inclusive education. The education office carries out the budget preparation process as the budget user agency. The relationship between the education office and inclusive schools to carry out inclusive education requires budget participation from both parties. However, it turns out that the communication between the education office and the inclusive schools has not run smoothly, which will cause budgetary slack. Research (Apriadinata, MD, Sujana, E., \& Adi Putra, 2014), (Dewi, NM, \& Sudana, 2013), (Djasuli, M., \& Fadilah, 2011), (Kartika, 2010), (Ikhsan, A., \& Ane, 2007), and (Falikhatun, 2007) prove that budget participation affects budgetary slack. Besides, the research presents evidence that participation reduces budgetary slack.

\section{$\mathrm{H}_{1}$ : Budget participation affects budgetary slack.}

Inclusive education that has been mandated by law since 2003 should have seen success in implementing inclusive education in education units. The success of inclusive education can be seen from the harmonious relationship between inclusive schools and the education office. This relationship will occur if inclusive schools can participate in the education office budget so that the needs of inclusive schools to carry out inclusive education can be met by the education office. The budget participation process has been running for more than 15 years to form an inclusive organizational culture in carrying out inclusive education between inclusive schools and the education office. Therefore, budget participation will create an inclusive organizational culture to educate children with disabilities sincerely and adequately. With an inclusive organizational culture that has been 
formed, inclusive schools and education offices will carry out quality inclusive education. This argument is supported by research (Makhrisza, Sutrasna, Yudi., 2018), which states that budget participation positively affects organizational culture.

$\mathrm{H}_{2}$ : Budget participation affects organizational culture.

Law No. 20 of 2003 and Law No. 8 of 2016, which mandate inclusive education, have been implemented by the education office through schools from elementary to high levels (President of the Republic of Indonesia, 2003). With this implementation, it will form a culture of inclusion to educate children with disabilities following children's needs. Supentanginingrum (2016) stated that creating an inclusive culture must always be fostered so that school members can realize inclusive education and learning practices that should be (Suprehiningrum, 2016). With an inclusive organizational culture, inclusive schools and education offices will communicate with each other in carrying out inclusive education so that no budgetary slack will occur because the budget is adjusted to the needs of the inclusive school. This argument is in accordance with Prawira and Wirasedana (2016) research, which stated that organizational culture affects budgetary slack (Prawira, H., \& Wirasedana, 2016).

$\mathrm{H}_{3}$ : Organizational culture affects budgetary slack.

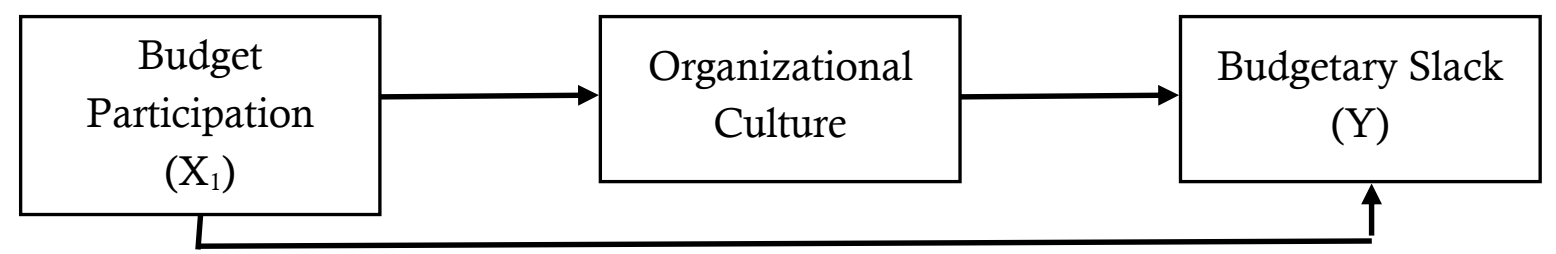

Figure 1. Empirical Research Model

\section{METHOD}

This research is a quantitative research type with a survey method so that the data used are primary data. The data used are questionnaire data from school principals in inclusive schools in Gunungkidul Regency and Gunungkidul district education office employees. They are involved in the budget process, so that the sampling was carried out by purposive sampling. The instrument of budget participation, organizational culture, and budgetary slack used in this study is an instrument with a Likert scale measured by five levels of answers, namely strongly agree, agree, doubt, disagree, and strongly disagree.

This study's population were all school principals in Gunungkidul Regency and all staff of the Gunungkidul Regency education office. This study used purposive sampling with the following criteria: principals of inclusive schools in Gunungkidul Regency and employees at the Gunungkidul Regency Education Office who work in inclusive school budgeting. This study involved principals of elementary and junior high school inclusion in Gunungkidul Regency and employees of the Gunungkidul Regency Education Office who work in the budgeting of inclusive schools, as follows: 
Table 1. Research Sample

\begin{tabular}{llll}
\hline No & & Explanation & Total \\
\hline 1. & Primary School & & 75 \\
2. & Junior High School & & 25 \\
3. & Gunungkidul Regency Education Office staff working in inclusive & 10 \\
& & \\
\hline & & School budgeting & \\
\hline
\end{tabular}

This study is using data collection methods by distributing research questionnaires to the research sample.

Table 2. Questionnaire Details in This Study

\begin{tabular}{lllll}
\hline Explanation & Spread out & Back & Incomplete & Processed \\
\hline $\begin{array}{l}\text { Questionnaires sent } \\
\text { (delivered live) }\end{array}$ & 135 & 125 & 15 & 110 \\
Primary School & 100 & 90 & 15 & 75 \\
Junior High School & 25 & 25 & 0 & 25 \\
Gunungkidul Regency Education & 10 & 10 & 0 & 10 \\
Office staff & & & & \\
\hline
\end{tabular}

The operational definition of variables in this study is as follows: 1) Budgetary slack is the difference between planned performance targets and actual performance capabilities (Douglas, P. C., \& Wier, 2000). Indicators regarding this budgetary slack are the difference in the budget stated with the best estimate, looseness in the budget, budget standards, and the desire to achieve the target (Onci, 1973). This variable was measured using 6 question items adopted from the study (Dunk, 1993); 2) Budget participation is a concept used to describe the extent to which subordinates are allowed to choose their programs in action (Milani, 1975). Indicators regarding budget participation are participation in budget preparation, the influence of budget targeting, and the influence of opinions given (Kenis, 1979). This variable was measured using five questions, which were adopted from Kenis's (1979) study; 3) Organizational culture is a culture formed as a result of a collective agreement that will make members of the organization have a sense of responsibility in implementing essential aspects of the organizational culture (Agusti, 2012). Indicators regarding this corporate culture are involvement, adaptation, consistency, and mission (Robbins, 1996). This variable was measured using 23 questions, which were adopted from Robbins' research (1996).

The quantitative data analysis technique in this study used Partial Least Squares (PLS). The use of PLS aims to analyze the relationship between complex variables that cannot be worked out using multiple regression, with the following conditions: the residuals are not correlated, the relationship between variables is linear and additive, and the amount of data is at least 10 data per variable (Gudono, 2012). PLS is very suitable for use in this study, which aims to predict models to develop theories. This research uses SmartPLS 3.0 software, which can be downloaded on the website http://www.smartpls.de.

This study conducted a research instrument test that aims to ensure that the questionnaire items are sufficient and correct according to respondents, assess the initial 
reliability of the scales, and determine the sample's size to be used in the primary research (Hartono, 2011). The research instrument test tested the reliability and validity. The sample size in the pilot test was around 10 to 30 respondents (Hartono, 2011).

The research instrument test in this study was conducted at 26 inclusive schools in Gunungkidul Gunungkidul Regency. The results of the research instrument test in this study are as follows:

Table 3. Research Instrument Test

\begin{tabular}{lcccc}
\hline & AVE & $\begin{array}{c}\text { Composite } \\
\text { Reliability }\end{array}$ & R Square & $\begin{array}{c}\text { Cronbach's } \\
\text { Alpha }\end{array}$ \\
\hline Organizational Culture & 0.955 & 0.943 & 0.149 & 0.937 \\
Budget Participation & 0.560 & 0.761 & & 0.788 \\
Budgetary Slack & 0.586 & 0.642 & 0.256 & 0.625 \\
\hline
\end{tabular}

Based on the research instrument test using PLS, it can be concluded that the validity and reliability have exceeded the requirements. For convergent validity, the loading factor and AVE values exceed 0.5. Meanwhile, the discriminant validity with the root AVE value exceeds the latent variable correlation. Reliability as measured by composite reliability and Cronbach's Alpha exceeds 0.6. (Hartono, 2011). Thus, all questionnaire items in this study can be used.

\section{FINDING AND DISCUSSION}

Data analysis in this study used PLS with the following stages:

a. Designing and Evaluating the Measurement Model (Outer Model)

Based on 110 questionnaires from the research sample consisting of 100 inclusion school principals and ten staff of the Education Office, the evaluation results of the measurement model (path analysis) can be presented using the PLS algorithm iteration:

Table 4. Evaluation Results of the Measurement Model

\begin{tabular}{lcccc}
\hline & $\boldsymbol{A V E}$ & $\begin{array}{c}\text { Composite } \\
\text { Reliability }\end{array}$ & $\boldsymbol{R}$ Square & Cronbach's Alpha \\
\hline $\begin{array}{l}\text { Organizational } \\
\text { Culture }\end{array}$ & 0.540 & 0.963 & 0.145 & 0.962 \\
Budget Participation & 0.533 & 0.848 & & 0.795 \\
Budgetary Slack & 0.585 & 0.890 & 0.145 & 0.868 \\
\hline
\end{tabular}

1) Construct Validity Test

The construct validity test is seen from the loading factor, average variance extracted (AVE), and R Square. Parameters for loading factor for each indicator measuring construct must exceed 0.50 . The parameters for average variance extracted (AVE) must each exceed 0.5. Based on the processing results, it turns out 
that the AVE score for the organizational culture construct is 0.540 , the budget participation construct is 0.533 , and the budgetary slack is 0.585 , which exceeds 0.50 . (Hartono, 2011).

\section{a) Convergent Validity Test}

The convergent validity test is seen based on the average variance extracted (AVE). Parameters for average variance extracted (AVE) must each be more than 0.5. Suppose the AVE score is more than 0.50 . In that case, the probability of the indicator in one construct entering another variable is lower (less than 0.5). The likelihood of the indicator and entering the construct in question is more significant, above 0.5 or equal to $50 \%$ (Hartono, 2011). Based on the processing results, all AVE scores from the three constructs have met the requirements by exceeding 0.5. The budget slack construct with the highest AVE score is 0.585, and the budget participation construct with the lowest score is 0.533 .

b) Discriminant Validity Test

The discriminant validity test can be seen by comparing the AVE roots for each construct with the correlation between one construct and another. Discriminant validity is fulfilled if the model AVE root score for each construct is greater than the correlation between one construct and another (Hartono, 2011). Based on the processing results, the AVE root exceeds the correlation coefficient between constructs, which means that all of these indicators meet the requirements of discriminant validity.

Table 5. Average Variance Extracted (AVE)

\begin{tabular}{llc}
\hline \multicolumn{1}{c}{ Indicator } & AVE & AVE root \\
\hline Organizational Culture & 0.540 & 0,734846922 \\
Budget Participation & 0.533 & 0,730068489 \\
Budgetary Slack & 0.585 & 0,764852927 \\
\hline
\end{tabular}

Table 6. Latent Variable Correlation

\begin{tabular}{lccc}
\hline & $\begin{array}{c}\text { Organizational } \\
\text { Culture }\end{array}$ & $\begin{array}{c}\text { Budget } \\
\text { Participation }\end{array}$ & $\begin{array}{c}\text { Budgetary } \\
\text { Slack }\end{array}$ \\
\hline Organizational Culture & 1.000 & & \\
Budget Participation & 0.381 & 1.000 & \\
Budgetary Slack & 0.354 & 0.197 & 1.000 \\
\hline
\end{tabular}

2) Reliability Test

The reliability test can be seen from the Cronbach's alpha score and the composite reliability score. The requirements for Cronbach's alpha and composite reliability must exceed 0.7 (Hartono, 2011). Based on the table, it can be seen that the Cronbach's alpha score and composite reliability for all constructs exceed 0.7 , so it can be concluded that all constructs in this study meet the reliability test. Thus, all 
instruments in this study meet the validity and reliability tests so that it is appropriate to test the hypothesis.

Table 7. Cronbach's Alpha and Composte Reliability Score

\begin{tabular}{lcc}
\hline & Cronbach's Alpha & Composite Reliability \\
\hline Organizational Culture & 0.962 & 0.963 \\
Budget Participation & 0.795 & 0.848 \\
Budgetary Slack & 0.868 & 0.890 \\
\hline
\end{tabular}

b. Designing and Evaluating the Structural Model (Inner Model)

In this structural model, 4 constructs consist of 1 exogenous construct (independent), two endogenous exogenous constructs, and one endogenous construct (dependent). The structural model in PLS can be evaluated based on the value of $\mathrm{R}^{\wedge} 2$ for the dependent construct and the value of the path coefficient (path) or t-value of each path for the independent variable, which is then tested for significance by looking at the T-statistic value for each path. (track) (Hartono, 2011).

Based on the PLS processing results, it can be seen that the R2 value for the organizational culture construct is 0.145 , and the budgetary constraint is 0.145 . In this research model, the $\mathrm{R} 2$ value for the constructs above for the organizational culture construct variable is $14.5 \%$, the budget slack construct is $14.5 \%$, while other variables outside the proposed model explain the rest.

c. Hypotheses Testing

Testing the structural model in PLS using the bootstrapping function is used to test the hypotheses proposed in this study. Below is presented the results of the bootstrapping processing:

Table 8. Path Coefficients (Path Coefficients; Mean, STDEV, T-Values)

\begin{tabular}{|c|c|c|c|c|c|c|}
\hline & & $\begin{array}{l}\text { Original } \\
\text { Sample } \\
\text { (O) }\end{array}$ & $\begin{array}{l}\text { Sample } \\
\text { Mean } \\
\text { (M) }\end{array}$ & $\begin{array}{l}\text { Standard } \\
\text { Deviation } \\
\text { (STDEV) }\end{array}$ & P-Value & $\begin{array}{c}\text { T Statistics } \\
(\mid \text { O/STERR } \mid)\end{array}$ \\
\hline $\begin{array}{l}\text { Organizational } \\
\text { Culture } \\
\text { Budgetary Slack }\end{array}$ & $->$ & 0.295 & 0.281 & 0.162 & 0.069 & 1.822 \\
\hline $\begin{array}{l}\text { Budget } \\
\text { Participation } \\
\text { Organizational } \\
\text { Culture }\end{array}$ & $->$ & 0.381 & 0.394 & 0.082 & 0.000 & 4.638 \\
\hline $\begin{array}{l}\text { Budget } \\
\text { Participation } \\
\text { Budgetary Slack }\end{array}$ & $->$ & 0.056 & 0.065 & 0.130 & 0.667 & 0.431 \\
\hline
\end{tabular}


Based on the three hypotheses proposed in this study, the results of processing using PLS analysis can be seen in the table above. Meanwhile, below will describe the research for processing results in hypothesis testing, as follows:

$\mathrm{H}_{1}$ : Budget participation affects budgetary slack.

Based on the path coefficient table above, it can be concluded that budget participation does not have a significant effect on budgetary slack. It can be seen from the T-statistic value of 0.431 , which is less than the required T-table value of 1.64 , and the path coefficient value $(\gamma 1)$ of 0.056 . Therefore, $\mathrm{H} 1$ is not supported. It means that budget participation in inclusive schools in Gunungkidul Regency has no significant effect on budgetary slack for inclusive schools in Gunungkidul Regency. This study's results support research (Alfebriano, 2013) and (Santoso, 2005), which found that budget participation does not affect budgetary slack.

Supposedly, budgetary participation in implementing inclusive education programs will reduce budgetary slack because inclusive schools will know more about the needs of inclusive education. In contrast, the education office has information about the budget for inclusive education. This does not happen because there is no conflict of interest between subordinates in the organization, so that the implementation of budget participation will not result in budgetary slack due to the high alignment between employee goals and SKPD (Kusniawati, Heny., \& Lahaya, Abni, 2017). Based on these arguments, it can be concluded that inclusive schools and the education office already have clear objectives to carry out inclusive education, no conflict of interest. Thus the implementation of budget participation will not cause budgetary slack.

$\mathrm{H}_{2}$ : Budget participation affects organizational culture.

Based on the path coefficient table above, it can be concluded that budget participation has a significant influence on organizational culture. This can be seen from the T-statistic value of 4,638, which exceeds the required T-table value of 1.64 , and the path coefficient $(\gamma 1)$ value of 0.381 . Therefore, $\mathrm{H} 2$ is supported (acceptable). This means that if the budget participation in inclusive schools in Gunungkidul Regency has increased, the inclusive school organization's culture in inclusive schools in Gunungkidul Regency will also increase, and vice versa. The results of this study support the research (Makhrisza, Sutrasna, Yudi., 2018) saying that budget participation affects organizational culture. With budget participation, the communication links to carry out inclusive education run well to form an inclusive organizational culture between inclusive schools and the education office.

H3: Organizational culture affects budgetary slack.

Based on the path coefficient table above, it can be concluded that organizational culture has a significant influence on budgetary slack. This can be seen from the Tstatistic value of 1,822 , which exceeds the required T-table value of 1.64 and the path coefficient $(\gamma 1)$ value of 0.295 . Therefore, H3 is supported (acceptable). This means that if the culture of the inclusive school organization in Gunungkidul Regency has increased, then the budgetary slack for inclusive schools in Gunungkidul Regency will decrease, and vice versa. This study's results support research (Prawira, H., \& Wirasedana, 2016), 
saying that organizational culture affects budgetary slack. With an inclusive organizational culture that has been formed between inclusive schools and the education office to carry out inclusive education, it will not cause budgetary slack because between inclusive schools and the education office already have the same goal, namely carrying out inclusive education.

Table 9. Summary of Hypothesis Testing Results

\begin{tabular}{llllll}
\hline Hypotheses & Relation & Sign & Coefficient & $\begin{array}{c}\text { T- } \\
\text { statistic }\end{array}$ & Result \\
\hline $\mathbf{H}_{1}$ & $\mathrm{BP} \rightarrow \mathrm{BS}$ & - & 0.056 & 0.431 & Unsupported \\
$\mathbf{H}_{2}$ & $\mathrm{BP} \rightarrow \mathrm{OC}$ & + & 0.381 & 4.638 & Supported \\
$\mathbf{H}_{3}$ & $\mathrm{OC} \rightarrow \mathrm{BS}$ & - & 0.295 & 1.822 & Supported \\
\hline
\end{tabular}

Note: $1,64 \mathrm{P}<0,05 ; 2,33 \mathrm{P}<0,01$ (one-tailed).

\section{Direct and Indirect Effect Analysis}

This study includes an intervening variable that connects budgetary participation and budgetary slack, namely the organizational culture variable. The stages for testing the moderation effect using intervening variables (Hartono, 2011) are: (1) testing the main effect of the independent variable on the dependent variable (the effect of budget participation on budgetary slack) must be significant, (2) testing the effect of independent variables on the mediating variable (budget participation to organizational culture) must be significant, and (3) examining the effect of the mediating variable on the dependent variable (organizational culture to budgetary slack), must be significant. Based on the results of the hypothesis testing above, the direct effect between budgetary participation on budgetary slack is not significant, although the indirect effect between budget participation on organizational culture and organizational culture on budgetary slack is significant. Therefore, it can be concluded that the organizational culture variable cannot function as an intervening variable that can mediate the relationship between budget participation and budgetary slack.

\section{CONCLUSION}

Based on the analysis and research discussion described above, it can be concluded that budget participation affects organizational culture and organizational culture affects organizational slack. Meanwhile, budget participation is not proven to affect budgetary slack.

This research is the first accounting research to consider budget participation in the inclusive school setting. However, the authors realize that this study has several limitations, including: (1) the sample only involved inclusive school principals who saw the perspective of internal parties only and (2) lack of control for respondents' answer caused by questionnaire method and possible response bias from self-assessment technique.

Regarding the results of this study, the government and inclusive schools must continue to encourage budgetary participation in carrying out inclusive education programs. It is expected to improve the culture of inclusive school organizations to reduce budgetary slack. Budget participation is essential because inclusive schools know more 
about running an inclusive education program, while the education office knows more about the budget to be used. Inclusive schools and education offices should continue to develop an inclusive organizational culture so that they can work well in running the inclusive education programs. By reducing budgetary slack, inclusive schools are expected to run inclusive education programs better.

Based on the results of this study, the authors propose several suggestions as follows: 1) Improve the quality of budget participation and encourage an organizational culture that supports inclusive education in schools to reduce budgetary slack. This is done so that inclusive schools can optimally run inclusive education programs by the mandate of Law No. 20 of 2003 and Law No. 8 of 2016 (President of the Republic of Indonesia, 2016). Education Office should encourage budget participation from inclusive schools so that the program and budget for implementing inclusive education can match inclusive schools' needs. Besides, Suprihatiningrum (2016) states that creating an inclusive culture must always be fostered so that school members can realize inclusive education and learning practices that should be (Suprihatiningrum, 2016); 2) Further research can expand the region's reach, for example, at the provincial or national level, and increase research respondents, such as involving inclusive school teachers; 3) Further research can examine procedural and behavioral aspects such as motivation or stress in implementing budget participation, factors that influence organizational culture related to the budget preparation process, and mechanisms for detecting and preventing budgetary slack; 4) Future research may use different analytical techniques. For example, multiple regression to determine the effect between variables, or correlation to determine the relationship between variables and covariance-based SEM if the variables used are more complex.

\section{REFERENCES}

Agusti, R. (2012). Pengaruh Partisipasi Penyusunan Anggaran Terhadap Kinerja Aparatur Pemerintah Daerah Dengan Dimoderasi Oleh Variabel Desentralisasi Dan Budaya Organisasi. Jurnal Ekonomi Universitas Riau, 20(3). https://je.ejournal.unri.ac.id/index.php/JE/article/view/1173.

Alfebriano. (2013). Faktor-Faktor yang Mempengaruhi Slack Anggaran pada PT BRI di Kota Jambi. E-Jurnal Binar Akuntansi. http://portalgaruda.fti.unissula.ac.id/index.php?ref=browse\&mod=viewarticle\&arti cle $=122435$.

Andiyani \& Ro'fah. (2014). Strategi Pembelajaran Adaptif Untuk Statistika. Inklusi, 1(1), 83-108. https://doi.org/10.14421/ijds.010105.

Anthony, R. N., \& Govindarajan, V. (2000). Management Control System. U.S.: The McGraw-Hill.

Apriadinata, M. D., Sujana, E., \& Adi Putra, M. P. (2014). Pengaruh Partisipasi Anggaran, Penekaanan Anggaran, Komitmen Organisasi, dan Asimetri Informasi terhadap Slack Anggaran dengan Kompleksitas Tugas sebagai Variabel Moderasi (Studi Kasus pada BPR di Kota Singaraja). E-Jurnal $S 1$ Ak Universitas Pendidikan, 2(1). 
Jurnal Economia, 17(1), April 2021, 49-64

http://dx.doi.org/10.23887/jimat.v2i1.4357.

Budi, T. A. (2013). Pengaruh Penganggaran Partisipatif Terhadap Budgetary Slck dengan Asimetri Informasi dan Budget Emphasis Sebagai Variabel Pemoderasi (Studi Kasus Pada PEMDA Kabupaten Sleman). UGM.

Dewi, N. M., \& Sudana, I. P. (2013). Pengaruh Penganggaran Partisipatif pada Senjangan Anggaran dengan Budgetary Control dan Komitmen Organisasi sebagai Variabel Pemoderasi. E-Jurnal Akuntansi Univervitas Udayana, 707-722. https://ojs.unud.ac.id/index.php/Akuntansi/article/view/7665.

Djasuli, M., \& Fadilah, N. I. (2011). Efek Interaksi Informasi Asimetri, Budaya Organisasi, Group Cohensiveness dan Motivasi dalam Hubungan Kausal antara Budgeting Partisipation dan Budgetary Slack. Jurnal PESAT Universitas Ganadarma, 4. http://repository.gunadarma.ac.id/id/eprint/1347.

Douglas, P. C., \& Wier, B. (2000). Integrating Ethical Dimensions Into A Model Of Budgetary Slack Creation. Journal Of Business Ethics, 28(3), 267-277. https://doi.org/10.1023/A:100624190201.

Dunk, A. S. (1993). The Effect of Budget Emphasis and Information Asymetry on the Relation between Budgetary Partisipaton and Slack. The Accounting Review, 68(2), 400410. https://www.jstor.org/stable/248408?seq=1.

Falikhatun. (2007). Interaksi Informasi Asimetri, Budaya Organisasi, dan Group Cohensiveness dalam Hubungan antara Partisipasi Penganggarann dan Budgetary Slack. SNA X.

Fikri, A. (2014). Partisipasi Politik Masyarakat Difabel Dalam Pembentukan Kebijakan Pendidikan Tinggi Inklusif. Inklusi, 1 (1), 110-128. https://doi.org/10.14421/ijds.010106.

Grediani, E. (2010). Pengaruh Tekanan dan Tanggungjawab Persepsian pada Penciptaan Budgetary Slack. UGM.

Gudono. (2012). Teori Organisasi. Jakarta: Salemba Empat.

Handayani, T., \& Rahadian, S. A. (2013). Peraturan Perundangan Dan Implementasi Pendidikan Inklusif. Jurnal Masyarakat Indonesia, 39 (1). https://doi.org/10.14203/jmi.v39i1.307.

Hanjarwati, A., \& Aminah, S. (2014). Evaluasi Implementasi Kebijakan Pemerintah Kota Yogyakarta Mengenai Pendidikan Inklusi. Inklusi, 1(2), 221-248. https://doi.org/10.14421/ijds.010206.

Hartono, J. (2011). Konsep Dan Aplikasi Structural Equation Modeling Berbasis Varian Dalam Penelitian Bisnis. Yogyakarta: UPP STIM YKPN.

Huda, K., Sinarwati, N. K., Herawati, N. T., \& AK, S. (2014). Pengaruh Partisipasi Anggaran Terhadap Senjangan Anggaran Dengan Budaya Organisasi Sebagai Variabel Pemoderasi. JIMAT Undiksha, 2(1). http://dx.doi.org/10.23887/jimat.v2i1.4378. 
Ikhsan, A., \& Ane, L. (2007). Pengaruh Partisipasi Anggaran terhadap Senjangan Anggaran dengan Menggunakan Lima Variabel Pemoderasi. SNA X.

Indriani, L., \& Yusuf, M. (. (2014). Pengaruh Partisipasi Anggaran Terhadap Kesenjangan Anggaran Dengan Budaya Organisasi Sebagai Variabel Pemoderasi. Presta, 13. http://ejournal.unp.ac.id/students/index.php/akt/article/view/113.

Jensen \& Meckling. (1976). Theory of the Firm: Managerial Behavior, Agency Costs, and Ownership Structure. Journal of Financial Economics, 3, 305-360. https://doi.org/10.1016/0304-405X(76)90026-X.

Kartika, A. (2010). The Effect of Organizational Commitment and Uncertainty Environment on The Relationship Between Budget Participation. Kajian Akuntansi, 2(2), 39-60. https://www.unisbank.ac.id/ojs/index.php/fe4/article/view/225.

Kenis, I. (1979). Effects Of Budgetary Goal Characteristics On Managerial Attitudes And Performance. The Accounting Review, 54(4), 707-721. https://doi.org/10.1590/19827849rac2020200047.

Kusniawati, Heny., \& Lahaya, Abni, I. (2017). Pengaruh Partisipasi Anggaran, Penekanan Anggaran, Asimetri Informasi terhadap Badgetary Slack pada SKPD Kota Samarinda. Akuntabel, 14(2). http://dx.doi.org/10.29264/jakt.v14i2.1904.

Magee, R. P. (1980). Equilibria in Budget Participation. Journal of Accounting Research. (http://www.jstor.org/stable/pdf/2490592.pdf).

Makhrisza, Sutrasna, Yudi., S. (2018). Pengaruh Partisipasi Anggaran, Budaya Organisasi, dan Teknologi terhadap Efektivitas Organisasi pada PT Pindad (Persero). Jurnal Ekonomi Pertahanan, $4(1)$. http://jurnalprodi.idu.ac.id/index.php/EP/article/view/190.

Mayasari. (2016). Implementasi Kurikulum 2013 Pada Anak Berkebutuhan Khusus. Inklusi: Journal Of Disability Studies, 1-1 8. https://doi.org/10.14421/ijds.030101.

Milani, K. (1975). The Relationship Of Participation In Budget-Setting To Industrial Supervisor Performance And Attitudes: A Field Study. The Accounting Review, 50(2), 274-284.

Onci, M. (1973). Factor Analysis of Behavioral Variables Affecting Budgetary Slack. The Accounting Review, 48(3), 535-548. https://www.jstor.org/stable/245151?seq=1.

Prawira, H., \& Wirasedana, P. I. (2016). Budaya Organisasi Sebagai Prediktor Partisipasi Penganggaran Dan Implikasinya Pada Senjangan Anggaran. E-Jurnal Akuntansi, 14(1), 144-171. https://ocs.unud.ac.id/index.php/Akuntansi/article/view/13748.

Presiden Republik Indonesia. (2003). UNDANG-UNDANG REPUBLIK INDONESIA NOMOR 20 TAHUN 2003 TENTANG SISTEM PENDIDIKAN NASIONAL. Jakarta: Sekretariat Negara.

Presiden Republik Indonesia. (2016). UU No. 8 tahun 2016. Jakarta: Sekretariat Negara.

Raharjo, E. (2007). Agency Theory and Stewardship Theory in the Accounting Perspective. 
Jurnal Economia, 17(1), April 2021, 49-64

Fokus Economi, 2(1), 37-46.

Robbins, S. P. (1996). Organizational Behavior: Concept, Controversies, Applications (7th Ed.) (7th ed.). Englewood Cliffs NJ: Prenticehall.

Santoso, S. (2005). Pengaruh Partisipasi Anggaran, Komitmen Organisasi, dan Keterlibatan Pekerjaan Terhadap Senjangan Anggaran pada Penyusunan APBD Kota Semarang. UGM.

Stroh, L. K., Brett, J. M., Baumann, J. P., \& Reilly, A. H. (1996). Agency Theory and Variable Pay Compensation Strategies. Academy of Mmanagement Journal, 39(3), 751767. https://journals.aom.org/doi/abs/10.5465/256663.

Suprihatiningrum, J. (2016). Persepsi Siswa Difabel Terhadap Praktik Pendidikan Inklusif Di SMA Inklusi Di Yogyakarta. INKLUSI: Journal Of Disability Studies, 3(2), 225-244. https://doi.org/10.14421/ijds.030204.

Tarnoto, N. (2016). Permasalahan-Permasalahan Yang Dihadapi Sekolah Penyelenggara Pendidikan Inklusi Pada Tingkat Sd. Humanitas, 13(1), 50-61. http://dx.doi.org/10.26555/humanitas.v13i1.3843.

Wati, E. (2014). Manajemen Pendidikan Inklusi Di Sekolah Dasar Negeri 32 Kota Banda Aceh. Jurnal Ilmiah DIDAKTIKA, XIV(2), 368-378. http://dx.doi.org/10.22373/jid.v14i2.508.

Witasoka, D. (2016). Manajemen Pendidikan Inklusif Sma Muhammadiyah Di Kota Yogyakarta. Inklusi: Journal of Disability Studies, 3(2), 163-192. http://dx.doi.org/10.22373/jid.v14i2.508.

Young, M. S. (1985). Participative Budgeting: The Effects of Risk Aversion and Asymmetric Information on Budgetary Slack. Journal of Accounting Research, 23(2), 829842. http://www.jstor.org/stable/pdf/2490840.pdf. 